\title{
Article
}

\section{The Activation of Mg Powder Promoted by Chloride and Activation Mechanism}

\author{
Xiaoxuan Wang ${ }^{1}$, Xiaoyan Guo ${ }^{1}$, Lixiang Zhu ${ }^{1}$, Shuo Wang ${ }^{1, *}$, Meishuai Zou ${ }^{1}, * \mathbb{C}$, Xiaodong Li ${ }^{1}$, \\ Xiaodong Zhang ${ }^{1}$ and Tinglu Song ${ }^{2}$ (1)
}

1 School of Materials Science and Engineering, Beijing Institute of Technology, Beijing 100081, China; 18434360254@163.com (X.W.); gxy@bit.edu.cn (X.G.); 3220201235@bit.edu.cn (L.Z.); bitlxd@bit.edu.cn (X.L.); 17854264182@163.com (X.Z.)

2 Experimental Center of Advanced Materials School of Materials Science \& Engineering, Beijing Institute of Technology, Beijing 100081, China; song@bit.edu.cn

* Correspondence: wangshuo@bit.edu.cn (S.W.); zoums@bit.edu.cn (M.Z.)

check for updates

Citation: Wang, X.; Guo, X.; Zhu, L.; Wang, S.; Zou, M.; Li, X.; Zhang, X.; Song, T. The Activation of Mg Powder Promoted by Chloride and Activation Mechanism. Metals 2021, 11, 1435 . https://doi.org/10.3390/met11091435

Academic Editors: Jean-Louis Bobet and Mieczyslaw Jurczyk

Received: 13 August 2021

Accepted: 7 September 2021

Published: 10 September 2021

Publisher's Note: MDPI stays neutral with regard to jurisdictional claims in published maps and institutional affiliations.

Copyright: (c) 2021 by the authors. Licensee MDPI, Basel, Switzerland. This article is an open access article distributed under the terms and conditions of the Creative Commons Attribution (CC BY) license (https:/ / creativecommons.org/licenses/by/ $4.0 /)$.

\begin{abstract}
Magnesium has bright market prospects such as generating thrust for under water engines and hydrogen production. However, the passive oxide film on the surface of magnesium powder prevents the further reaction of magnesium with water at room temperature. In this paper, highly active magnesium-based materials were prepared via ball milling pure $\mathrm{Mg}$ with different chlorides $\left(\mathrm{NiCl}_{2}, \mathrm{CoCl}_{2}, \mathrm{CuCl}_{2}, \mathrm{FeCl}_{3}\right)$. The activity of the as obtained powder was analyzed through Scanning Electron Microscopy (SEM), Energy dispersive X-ray spectroscopy (EDS), X-ray photoelectron spectroscopy (XPS), synchrotron X-ray tomography, Extended X-ray Absorption Fine Structure (EXAFS), etc. Among the various compositions, the $\mathrm{Mg}-6 \% \mathrm{CoCl}_{2}$ composite exhibited the best hydrogen production performance with a hydrogen generation volume of $423 \mathrm{~mL} /(0.5 \mathrm{~g})$ and a conversion yield of $96.6 \%$. The related activation mechanism was thoroughly studied, showing that the addition of chloride during ball milling can effectively break the continuity of oxide films on $\mathrm{Mg}$ surfaces and introduces a large number of micro defects. In addition, the EXAFS and tomography data verified that metallic cobalt was generated during the ball milling process, subsequently forming a $\mathrm{Mg}$-Co micro glance cell, and the $\mathrm{Cl}^{-}$in the system accelerates the corrosion of $\mathrm{Mg}$. The active mechanism can be verified as synergistic effects of micro glance cell and as-generated surface microcracks.
\end{abstract}

Keywords: hydrogen production; magnesium powder activation; ball-milling; activation mechanism

\section{Introduction}

As a promising new energy source [1-3], magnesium-based materials with unique physical and chemical properties, exhibit high mass and volume energy density [4,5]. The abundant resources of magnesium in the earth (contents in crust and seawater are $2.4 \%$ and $0.13 \%$, respectively) and low cost make it a promising candidate material for energy storage and energy conversion [6,7]. Magnesium has been employed in various applications. For instance, the burning of $\mathrm{Mg}$ in $\mathrm{CO}_{2}$ showed high specific impulse performance [8-10], and the realization of high-efficiency powder ignition will determine the future application prospects of the engine [10]. Magnesium could react easily with water with high reaction speed and efficiency [11-13]. Interestingly, magnesium could achieve ecofriendly hydrolysis reaction with high purity hydrogen and nano-size $\mathrm{Mg}(\mathrm{OH})_{2}$. However, once the hydrolysis reaction begins, a dense oxide film will generate on the surface of the magnesium, which would highly reduce the activity of magnesium powder [13-16]. To solve this problem, the development of novel material systems and multiple modification processes have been reported. The modification of magnesium-based materials, as well as the optimization of the hydrolysis process, has received much attention $[17,18]$. Current research on the activation of $\mathrm{Mg}$ mainly focuses on ball-milling modification. Grosjean et al. $[19,20]$ found that the specific surface area of $\mathrm{Mg}$ powder decreased linearly along 
with the increase of milling time, and correspondingly, the hydrolysis conversion rate increased from $9 \%$ to $26 \%$. Huang et al. [21] mixed Mo and its compounds with $\mathrm{Mg}$ via ball milling, and found that $\mathrm{Mg}-10 \mathrm{wt} \% \mathrm{MoS}_{2}$ exhibited excellent hydrogen production efficiency by hydrolysis in seawater. The excellent catalytic effect was mainly attributed to the synergistic effect introduced by the addition of catalyst. On one hand, the specific surface area of $\mathrm{Mg}$ enhanced the mechanical crushing effect during the ball milling process. On the other hand, the $\mathrm{Mg}$ could form a galvanic in the seawater medium, which promotes the corrosion of $\mathrm{Mg}$. Huang et al. [22] investigated the activity of $\mathrm{Mg}$ powder with $\mathrm{Co}_{3} \mathrm{O}_{4}$ addition during ball milling, which can produce $\mathrm{Mg}$ powders with smaller size and higher specific surface area. Furthermore, the $\mathrm{Co}_{3} \mathrm{O}_{4}$ accelerated reaction rates of $\mathrm{Mg}$ powder compared to pure $\mathrm{Mg}$ milled powders. Zou et al. [23] prepared highly reactive $\mathrm{Mg}-\mathrm{Al}-$ based hydro-reactive materials using high-energy ball milling. The Mg-Al hydro-reactive materials had excellent hydrolysis performance and could react completely with seawater in a short time, which showed the feasibility of its utilization for green energy production. Matsuzaki et al. [24] studied the hydrogen production performance of $\mathrm{Mg}$ chips generated via the hydrolysis reaction in seawater by machining. A notable improvement in hydrogen formation production was observed after ball milling and the hydrolysis reaction rate can be enhanced by the presence of $\mathrm{NaCl}$ in water. The addition of Ni during ball milling showed little impact in the hydrolysis reaction within non-conductive media. Grosjean et al. [20] found a significant increase of the $\mathrm{H}_{2}$ production by milling $\mathrm{Mg}$ sample with chloride ions for $30 \mathrm{~min}$. They explained that the ball milling process would induce defects and accentuation of the pitting corrosion by $\mathrm{Cl}^{-}$. Kravchenko et al. [25] investigated the oxidation processes of $\mathrm{Mg}, \mathrm{Mg}$ alloys with $\mathrm{Ni}, \mathrm{Co}, \mathrm{Cu}$ powder mixtures and ball milling alloy. Nearly stoichiometric amounts of hydrogen in respect to $\mathrm{Mg}$ can be obtained at production rates of up to $640 \mathrm{~mL} \cdot / \mathrm{g}^{-1} \times \mathrm{min}^{-1}$ by oxidation of Mg-Co alloy or mechanically processed Mg-Co powder ("mechanical alloy") in aqueous solutions of Na or K chlorides. Activator metals are not oxidized during this reaction. They assumed that $\mathrm{Mg}$ oxidation is the result of the electrochemical corrosion.

Besides the studies of $\mathrm{Mg}$-metal activated composites and the reaction of $\mathrm{Mg}$ with chloride solutions, chloride salts were also proven to be effective in activating the hydrolysis of $\mathrm{Mg}$ in neutral water. Liu et al. [26] found that the $6 \mathrm{~h}$-milled $\mathrm{Mg}-3 \mathrm{~mol} \% \mathrm{AlCl}_{3}$ exhibited excellent performance with a hydrogen yield of $93.86 \%$ and IHGR (initial hydrogen generation rate) of $455.9 \mathrm{~mL} \mathrm{~min}^{-1}(\mathrm{~g} \mathrm{Mg})^{-1}$ within $1 \mathrm{~h}$. Wang et al. [27] investigated the effect of $\mathrm{Co}$ or $\mathrm{Ni}$ and anions on $\mathrm{Mg}-\mathrm{H}_{2} \mathrm{O}$ reaction. Hydrogen was rapidly generated after adding $\mathrm{Mg}$ to an aqueous $\mathrm{CoCl}_{2}$ solution due to the synergistic reaction of the pitting of $\mathrm{Cl}^{-}$ions, the micro galvanic cells and the active $\mathrm{Co}$ or $\mathrm{Ni}$ formed by oxidization/reduction reaction. The results from Sun et al. [28] indicated that the activated $\mathrm{Mg}-\mathrm{CoCl}_{2}$ composites are very promising materials for hydrogen generation. The hydrolysis reaction of the $\mathrm{Mg}-6 \% \mathrm{CoCl}_{2}$ composite initiated immediately when immersed in pure water $\left(50^{\circ} \mathrm{C}\right)$.

The above studies show that chloride is effective in promoting the hydrolysis reaction of ball milling Mg. However, no detailed mechanism was revealed. In this work, we firstly studied the activity of ball-milled magnesium powder containing different chloride salts ( $6 \% \mathrm{NiCl} 2,6 \% \mathrm{CoCl} 2,6 \% \mathrm{CuCl} 2,6 \% \mathrm{FeCl} 3)$. We then studied the inner morphology of ball milling $\mathrm{Mg}-6 \% \mathrm{CoCl} 2$ composite using synchrotron X-ray tomography and the valence state of cobalt through EXAFS. The synergistic effects of ball milling, micro-galvanic corrosion, and modification effect of $\mathrm{Cl}$ - are attributed to the activation of $\mathrm{Mg}$.

\section{Experimental}

\subsection{Material Preparation}

Magnesium powder (60-300 mesh, 99 wt. \% purity), $\mathrm{NiCl}_{2}, \mathrm{CoCl}_{2}, \mathrm{CuCl}_{2}$, and $\mathrm{FeCl}_{3}$ (AR $\geq 99.5 \%$ purity) are the raw materials, the chloride content of ball milling is 6 percent of the mass fraction of $\mathrm{Mg}$ [28]. The milling process parameters are provided in Table 1. Masses of raw materials and water are $0.5 \mathrm{~g}$ and $10 \mathrm{~g}$, with water to fuel ratio of 20:1. 
Table 1. Ball milling parameters.

\begin{tabular}{cc}
\hline Ball Milling & Parameters \\
\hline Milling balls & Steel ball; diameter: $5 \mathrm{~mm}$ \\
Ball milling speed & $500 \mathrm{r} / \mathrm{min}$ \\
Ball milling atmosphere & Argon \\
Ball milling time & $3 \mathrm{~h}$ \\
Ball/material mass ratio & $40: 1$ \\
\hline
\end{tabular}

\subsection{Hydrolysis Experiment}

The hydrolysis reaction was conducted at room temperature and under atmospheric pressure. As shown in Figure 1, the hydrogen production reaction was performed in a $100 \mathrm{~mL}$ three-necked flask, one neck for water addition, one neck for hydrogen outlet, and one neck for temperature measurement. The hydrogen generated flowed through a condenser pipe and drying tube to remove water vapor before passing through the gas mass flow sensor (MEMS-FS4008). The gas mass flow sensor was connected to a computer to record the instantaneous rate of gas and cumulative flow. The hydrogen production performance of each formulation was repeated at least 3 times.

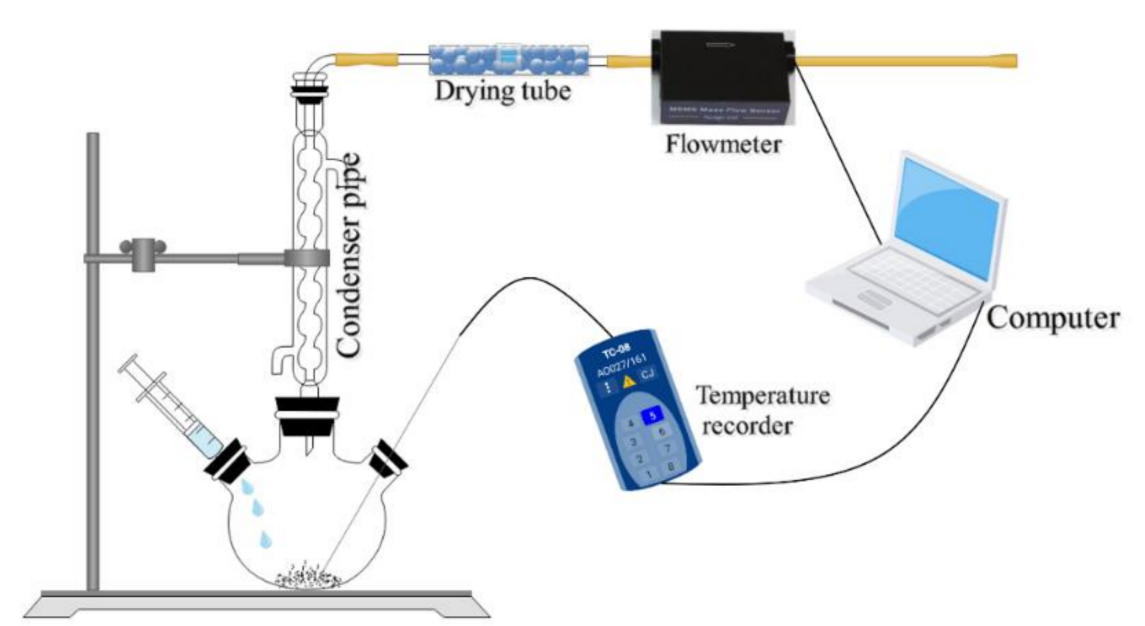

Figure 1. Schematic of the experimental installation for measuring hydrogen.

\subsection{Characterization Tests}

The samples were analyzed by powder X-ray diffraction (XRD) using an X'Pert PRO MPD diffract meter (PANalytical, Almelo, Netherlands) with $\mathrm{Cu} \mathrm{K} \alpha$ radiation, the diffraction angle was selected from 2 to $90^{\circ}$. The sample morphologies were observed by FESEM S4800 (Hitachi Instruments Equipment, Tokyo, Japan) scanning electron microscopy (SEM) and the corresponding elemental mapping of the sample was obtained by energydispersive spectroscopy (EDS). The samples' binding energies were analyzed by powder X-ray photoelectron spectroscopy (XPS) using PHI QUANTERA-II SXM equipment (Ulvacphi Corporation, Kanagawa, Japan). The temperature change during the reaction was tested by a K-type thermocouple and recorded using a thermal recorder connecting to the computer. Tafel curve passed the test of 660E electrochemical platform. The Co K-edge XAFS and nano tomography measurements were performed at the beamline 4B9A and 4W1A-X of the Beijing Synchrotron Radiation Facility (BSRF) at the Institute of High Energy Physics (IHEP), Chinese Academy of Sciences (CAS).

\section{Results}

\subsection{Characterization of Active $\mathrm{Mg}$}

All the raw materials show strong crystalline Mg peaks such as the XRD patterns shown in Figure 2. The Mg peaks of pure $\mathrm{Mg} / \mathrm{Mg}$-chloride structures after ball milling 
and the $\mathrm{Mg}$ standard card are almost constant, only showing a difference in peak intensity. It shows that the crystal forms of $\mathrm{Mg}$ in the raw materials after ball milling are all the same, and the crystallinity of different crystal forms of $\mathrm{Mg}$ has changed after adding different chlorides.

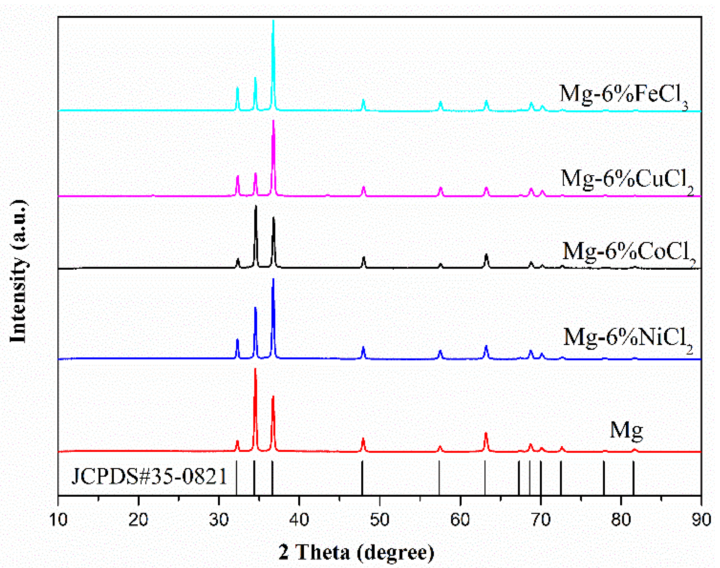

Figure 2. XRD patterns of Mg and Mg-chloride composites after ball-milling.

Figure 3 shows the SEM image of unmilled Mg, ball-milled Mg powder and the Mg-chlorides. All the spherical powders changed into flakes after ball milling. More structural defects were observed on the particles' surface after ball milling with chloride. This indicates that the oxide surface of the pure Mg powder can be effectively broken during the ball-milling process by adding chloride, exposing more reactive sites for the contact reaction between $\mathrm{Mg}$ and water.
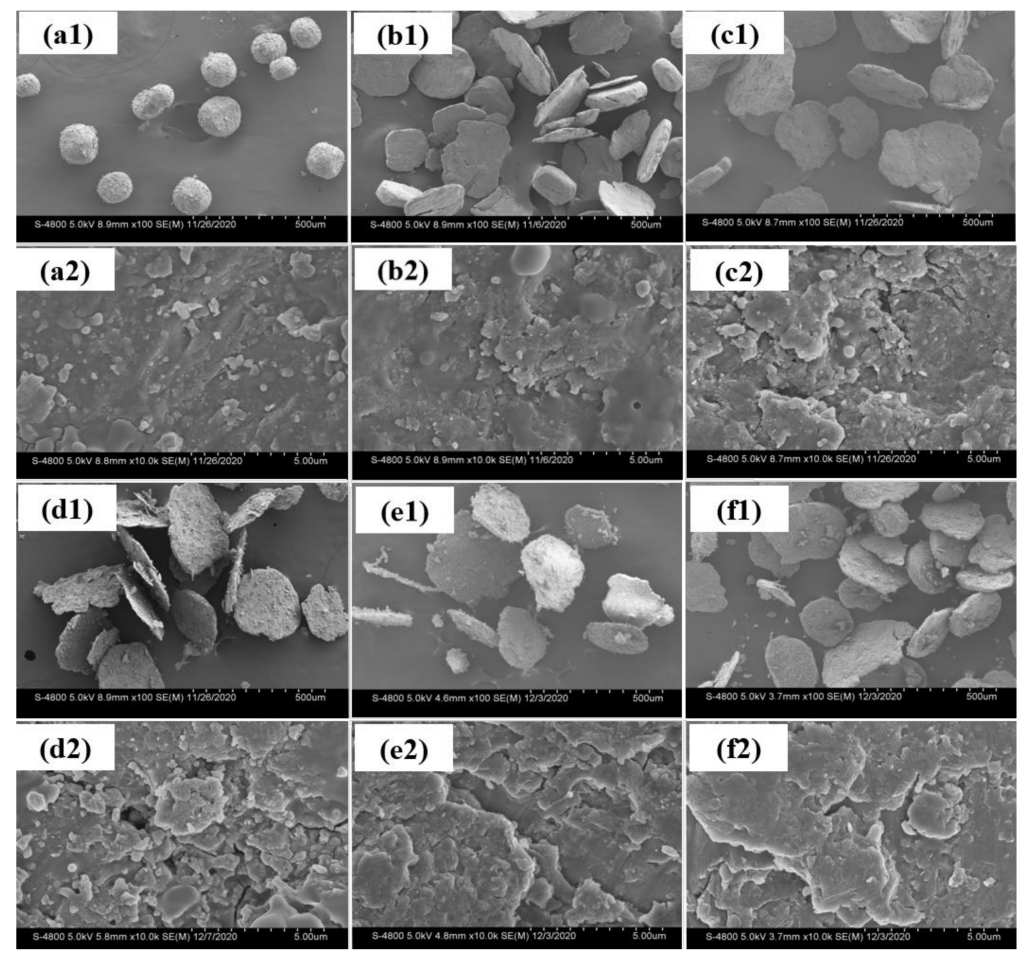

Figure 3. SEM images of unmilled $\mathrm{Mg}$, ball-milled $\mathrm{Mg}$ and $\mathrm{Mg}$-chlorides composites: (a1) unmilled $\mathrm{Mg}$ powder, (b1) ball-milled pure $\mathrm{Mg}$, (c1) $\mathrm{Mg}-6 \mathrm{wt} . \% \mathrm{NiCl}_{2},(\mathbf{d} 1) \mathrm{Mg}-6 \mathrm{wt} . \% \mathrm{CoCl}_{2}$, (e1) $\mathrm{Mg}$ $6 \mathrm{wt} . \% \mathrm{CuCl}_{2}$, (f1) $\mathrm{Mg}-6 \mathrm{wt} . \% \mathrm{FeCl}_{3}$. (a2-f2) are the corresponding amplified images. 
XPS spectra were performed to investigate the electronic environment of $\mathrm{Mg}$ in different composites. The $\mathrm{Mg}$ element exists in two forms of pure $\mathrm{Mg}$ and $\mathrm{MgO}$ from the XPS spectra shown in Figure 4. The binding energy of elemental $\mathrm{Mg}$ is about $49.91 \mathrm{eV}$ for ball-milled pure $\mathrm{Mg}$. The $\mathrm{MgO}$ peak has a large area which indicates the existence of a large amount of oxidation on the surface. However, after adding chloride during ball milling, the binding energies of $\mathrm{Mg}$ are lower than that of pure $\mathrm{Mg}$. The binding energies of elemental $\mathrm{Mg}$ in $\mathrm{Mg}-6 \% \mathrm{NiCl}_{2}, \mathrm{Mg}-6 \% \mathrm{CoCl}_{2}, \mathrm{Mg}-6 \% \mathrm{CuCl}_{2}$ and $\mathrm{Mg}-6 \% \mathrm{FeCl}_{3}$ are $49.77 \mathrm{eV}, 49.14 \mathrm{eV}, 49.86 \mathrm{eV}$ and $48.81 \mathrm{eV}$, respectively. The lower binding energy reveals that the addition of chloride can effectively destroy the surface oxide film and leads to the explosion of non-oxide $\mathrm{Mg}$, and this is consistent with the SEM images in Figure 3.

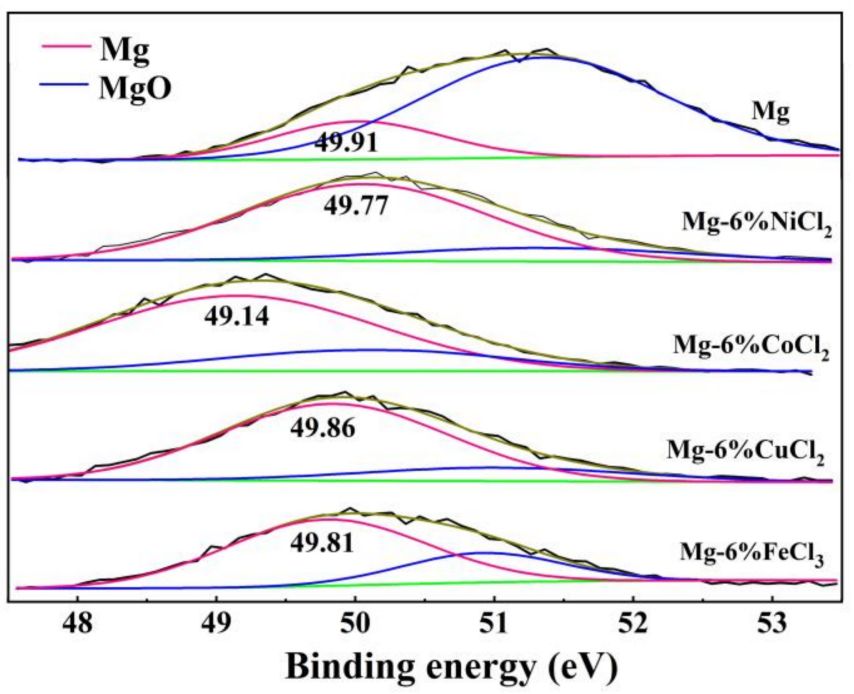

Figure 4. XPS spectra of the ball-milled Mg-chloride.

\subsection{The Hydrolysis Properties of Active Mg with Different Chlorides}

\subsubsection{Hydrogen Generation Property}

The hydrogen generation rate curves together with the temperature evolution curves during the hydrolysis processes for $\mathrm{Mg}$-chloride with water were recorded as shown in Figure 5 and Table 2, respectively. The ball-milled pure Mg powders can hardly react with water, and no hydrogen is detected. The hydrogen generation curves for Mg-chloride composites show a very rapid $\mathrm{H}_{2}$ release in the first reaction stage followed by an abrupt drop of the reaction rate as shown in Figure $5 b$. The rapid $\mathrm{H}_{2}$ release durations are different for different reaction systems, the values change from $\sim 50 \mathrm{~s}$ (for $\mathrm{NiCl}_{2}$ composite) to $\sim 20 \mathrm{~s}$ (for $\mathrm{FeCl}_{3}$ and $\mathrm{CuCl}_{2}$ composites). The drop of the hydrolysis reaction rate is due to the well-known formation of passive $\mathrm{Mg}(\mathrm{OH})_{2}$ layer onto the $\mathrm{Mg}$ powder surface [20], which prevents further contact between water and unreacted $\mathrm{Mg}$ material and leading to low conversion yields $(<80 \%)$. However, the $\mathrm{H}_{2}$ release rate maintains a high value for all the reaction periods for the $\mathrm{Mg}-\mathrm{CoCl}_{2}$ composite, resulting in a better hydrolysis performance than the other Mg-chloride composites with the highest hydrogen generation conversion yield of $96.6 \%$ as shown in Table 2. The reaction temperature curves also reflect the different heat release conditions. The hydrolysis reaction of magnesium is exothermic, and the temperature change curve during the reaction can also reflect its hydrogen generation rate. High $\mathrm{H}_{2}$ release rate can remove the generated $\mathrm{Mg}(\mathrm{OH})_{2}$ on the surface and lead to the exposure of unreacted $\mathrm{Mg}$, which promotes the further contact hydrolysis reaction of $\mathrm{Mg}$ and water. 

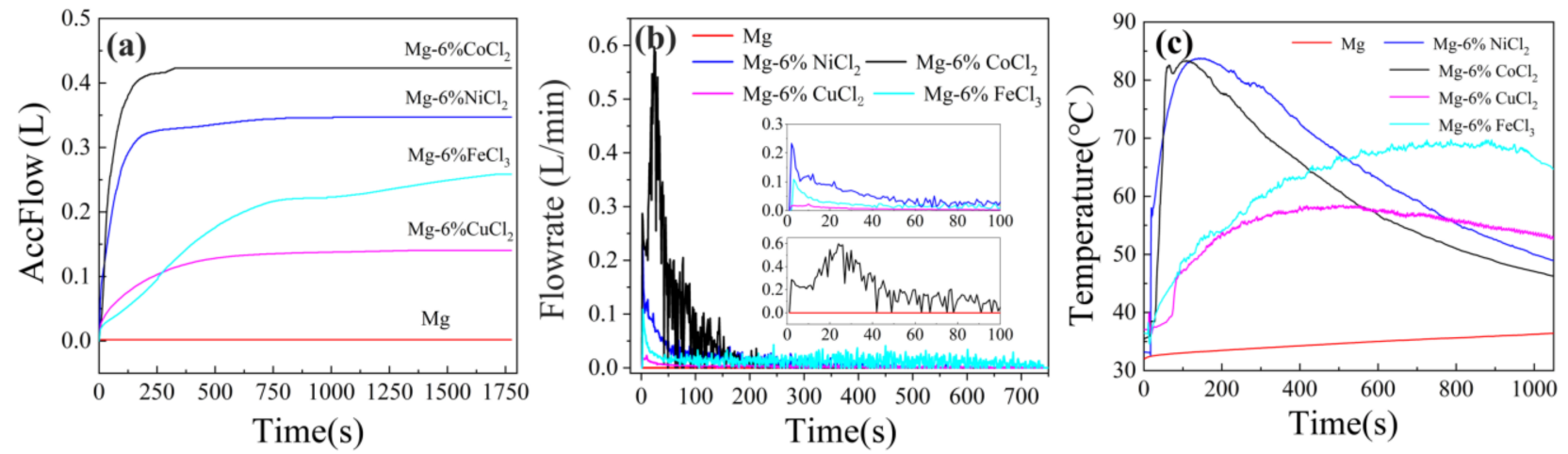

Figure 5. Hydrogen generation curves of the Mg-chloride with water (a), the hydrogen generation rate curves (b) and the temperature evolution curves (c).

Table 2. Hydrogen generation properties of ball-milled Mg-chloride with water.

\begin{tabular}{ccccc}
\hline Sample (0.5 g) & $\begin{array}{c}\text { Hydrogen Generation } \\
\text { Volume (L) }\end{array}$ & $\begin{array}{c}\text { Conversion } \\
\text { Yield (\%) }\end{array}$ & $\begin{array}{c}\text { Maximum Hydrogen } \\
\left.\text { Generation Rate (L.min } \mathbf{~}^{-1}\right)\end{array}$ & $\begin{array}{c}\text { Reaction Duration } \\
\text { (s) }\end{array}$ \\
\hline $\mathrm{Mg}$ & 0.002 & 4.28 & 0.001 & 5 \\
$\mathrm{Mg}-6 \% \mathrm{NiCl}_{2}$ & 0.347 & 79.2 & 0.434 & 276 \\
$\mathrm{Mg}-6 \% \mathrm{CoCl}_{2}$ & 0.423 & 96.6 & 0.597 & 325 \\
$\mathrm{Mg}-6 \% \mathrm{CuCl}_{2}$ & 0.141 & 32.2 & 0.153 & 830 \\
$\mathrm{Mg}-6 \% \mathrm{FeCl}_{3}$ & 0.258 & 58.9 & 0.157 & 1684 \\
\hline
\end{tabular}

Note: duration refers to the time from the beginning of the reaction to the time when maximum hydrogen production is reached.

\subsubsection{The Characteristics of Hydrolysis Products}

The XRD patterns of the products after hydrolysis reaction of Mg-chlorides with water were illustrated in Figure 6. All products show strong peaks of $\mathrm{Mg}(\mathrm{OH})_{2}$ except the ball milling $\mathrm{Mg}$ powder. No $\mathrm{Mg}$ peak can be detected in the $\mathrm{Mg}-\mathrm{CoCl}_{2}$ system, which indicates complete reaction for ball-milled $\mathrm{Mg}-\mathrm{CoCl}_{2}$.

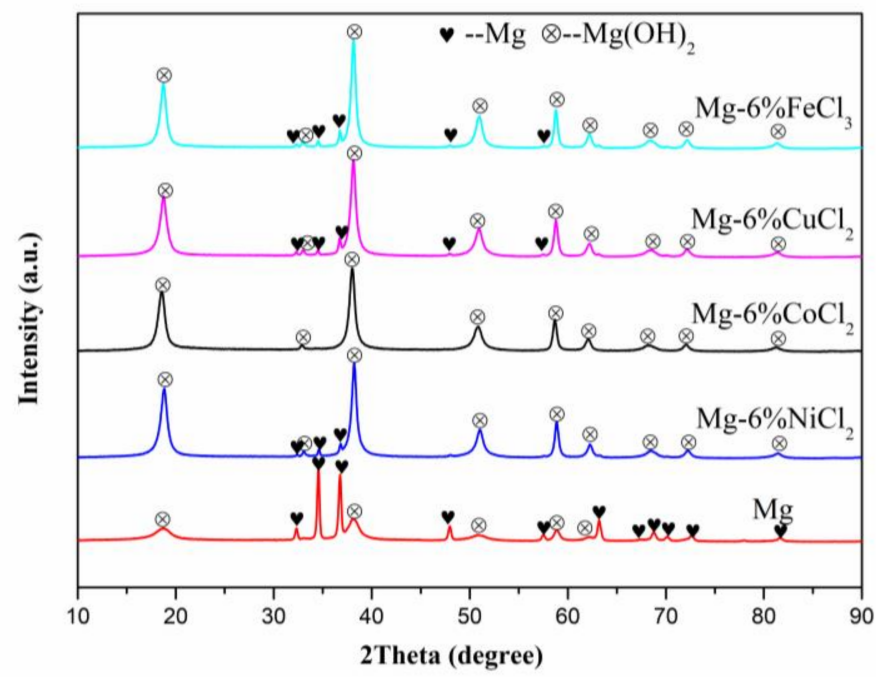

Figure 6. XRD of products after Mg-chlorides reacted with water.

The SEM images and EDS for hydrolysis reaction products of Mg-chlorides are shown in Figure 7. The $\mathrm{Mg}(\mathrm{OH})_{2}$ produced by the hydrolysis reaction is in the form of nano-sized flakes but with different morphologies and sizes. The $\mathrm{Mg}(\mathrm{OH})_{2}$ flakes from the production of $\mathrm{Mg}$-water reaction is laid on the surface with large size, which cover the unreacted $\mathrm{Mg}$ surface and block the further hydrolysis reaction. However, the product exhibits separated 
nano-sized particles clusters for all $\mathrm{Mg}$-chlorides systems. The $\mathrm{Mg}(\mathrm{OH})_{2}$ flakes of $\mathrm{Mg}$ $\mathrm{NiCl}_{2}$ and $\mathrm{Mg}-\mathrm{CoCl}_{2}$ hydrolysis reaction systems have self-assembled hexagonal nanoplate morphology. Whereas, the $\mathrm{Mg}(\mathrm{OH})_{2}$ flakes present irregular aggregated plate morphology with a smaller size for products of $\mathrm{Mg}-\mathrm{CuCl}_{2}$ and $\mathrm{Mg}-\mathrm{FeCl}_{3}$ hydrolysis reaction systems. This phenomenon may be the result of thermal conditions in the reaction systems.

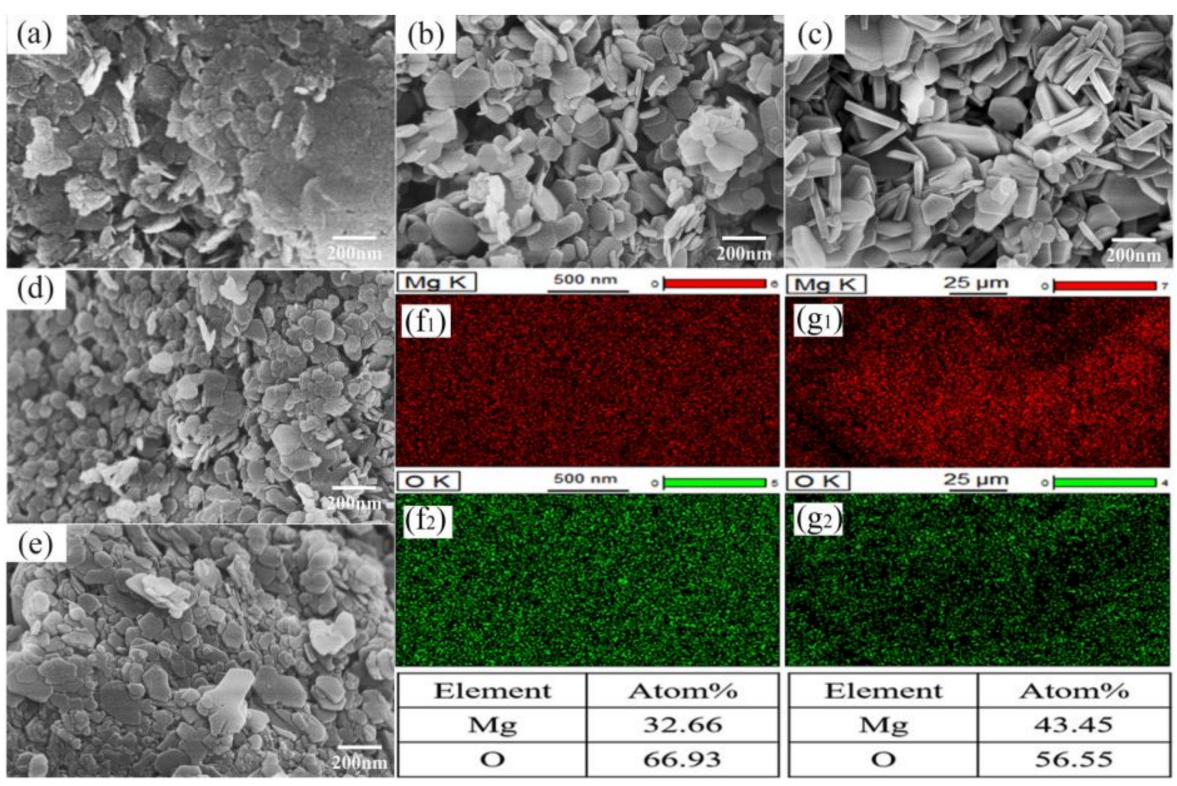

Figure 7. SEM images of products: (a) Pure $\mathrm{Mg}$, (b) $\mathrm{Mg}-6 \% \mathrm{NiCl}_{2}$, (c) $\mathrm{Mg}-6 \% \mathrm{CoCl}_{2}$, (d) $\mathrm{Mg}-6 \% \mathrm{CuCl}_{2}$, (e) $\mathrm{Mg}-6 \% \mathrm{FeCl}_{3}$. (f,g) are the EDS images of (c) product of $\mathrm{Mg}-6 \% \mathrm{CoCl}_{2}$, respectively.

The temperature curves in Figure $5 \mathrm{c}$ reflect the large temperature changes for $\mathrm{Mg}$ $\mathrm{NiCl}_{2}$ and $\mathrm{Mg}-\mathrm{CoCl}_{2}$ hydrolysis reaction systems which cause the large nucleation and growth rate, resulting in a large amount of $\mathrm{Mg}(\mathrm{OH})_{2}$ nucleation in a short time with a large growth rate. However, the new $\mathrm{Mg}(\mathrm{OH})_{2}$ nuclei always form easily on the existing ones under small thermal change conditions, and aggregated morphology forms for $\mathrm{Mg}$ $\mathrm{FeCl}_{3}$ and $\mathrm{Mg}-\mathrm{CuCl}_{2}$ hydrolysis reaction systems. In addition, the atomic ratio of $\mathrm{O}$ to $\mathrm{Mg}$ is studied to reveal the reaction extent. For $\mathrm{Mg}-6 \% \mathrm{CuCl}_{2}$, the atomic ratio of $\mathrm{O}$ to $\mathrm{Mg}$ of the product is less than 2, while for $\mathrm{Mg}-6 \% \mathrm{CoCl}_{2}$, the atomic ratio is close to 2. This indicates the existence of unreacted $\mathrm{Mg}$ between $\mathrm{Mg}-6 \% \mathrm{CuCl}_{2}$ and water. This phenomenon corresponds well with the XRD results in Figure 6.

\section{Discussions}

\subsection{The Different Activation Effects of Different Chlorides}

Electrochemical measurements were employed to investigate the different effects of chlorides on the reaction rate of the ball-milled $\mathrm{Mg}$-chloride with water. Figure 8 shows the Tafel curves of these materials. The corrosion potential for samples of pure $\mathrm{Mg}, \mathrm{Mg}-6 \% \mathrm{NiCl}_{2}, \mathrm{Mg}-6 \% \mathrm{CoCl}_{2}, \mathrm{Mg}-6 \% \mathrm{CuCl}_{2}$ and $\mathrm{Mg}-6 \% \mathrm{FeCl}_{3}$ are $-0.991 \mathrm{~V},-1.386 \mathrm{~V}$, $-1.596 \mathrm{~V},-1.104 \mathrm{~V}$ and $-1.232 \mathrm{~V}$, respectively. After ball milling with chlorides, the corrosion potential of $\mathrm{Mg}$ in water decreases by about $0.4-0.7 \mathrm{~V}$, which means that the $\mathrm{Mg}$ in $\mathrm{Mg}$-chloride composites is hydrolyzed easier in water. Lower corrosion potential with a higher reaction rate is the result of the hydrogen generation rate shown in Figure $5 \mathrm{~b}$. In addition, two corrosion potentials appear in the curve of the $\mathrm{Mg}-\mathrm{FeCl}_{3}$ composite, which may be related to the presence of divalent and trivalent iron during the reaction. 


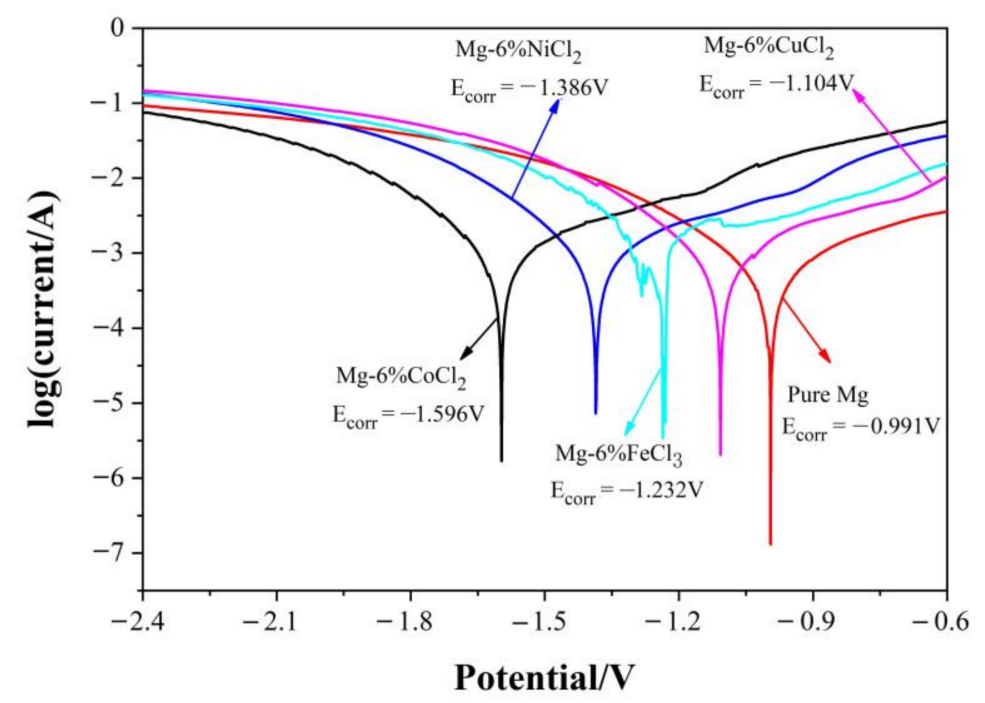

Figure 8. Tafel curves of the ball-milled Mg-chloride.

\subsection{The Effects of Co on the Activation of $M g$ Powder}

Chloride is proven to be very effective in the activation of $\mathrm{Mg}$ during the ball milling process. However, we cannot verify whether the effective ions are metal cations or chloride. Thus, we designed a set of comparative experiments to reveal the effect of chloride on the activation of $\mathrm{Mg}$ powder. Here, we take the $\mathrm{Mg}-\mathrm{CoCl}_{2}$ system as the investigated object for its good hydrogen generation performance. Metal Co powder was added during the ball milling process instead of chloride (6\% weight percent) using the same parameters as listed in Table 1 . The hydrolysis reactions were conducted in both tap water and $6 \% \mathrm{NaCl}$ solute with the same parameters as the $\mathrm{Mg}-\mathrm{CoCl}_{2}$ composite. In this way, we can justify the activation mechanism in $\mathrm{Mg}$-chloride composites.

The hydrogen production and hydrogen production rate are not detected by the flow meter for the reaction of $\mathrm{Mg}-6 \% \mathrm{Co}$ with tap water. This means the reaction between $\mathrm{Mg}$ $6 \% \mathrm{Co}$ and tap water is very slight. The tap water was then replaced with $\mathrm{NaCl}$ solution $(6 \%$ in weight percent). The hydrogen production performance is shown in Figure $9 \mathrm{a}, \mathrm{b}$ together with the data as listed in Table 3. The hydrogen yield of pure magnesium in $\mathrm{NaCl}$ solution is $0.108 \mathrm{~L}$ with the highest hydrogen degeneration rate of $0.132 \mathrm{~L} / \mathrm{min}$. This means that the $\mathrm{NaCl}$ solute is effective in enhancing the hydrolysis reaction of pure $\mathrm{Mg}$. The hydrogen yield is greatly enhanced for ball milling $\mathrm{Mg}-6 \%$ Co compared with pure $\mathrm{Mg}$ with a higher maximum hydrogen generation rate.
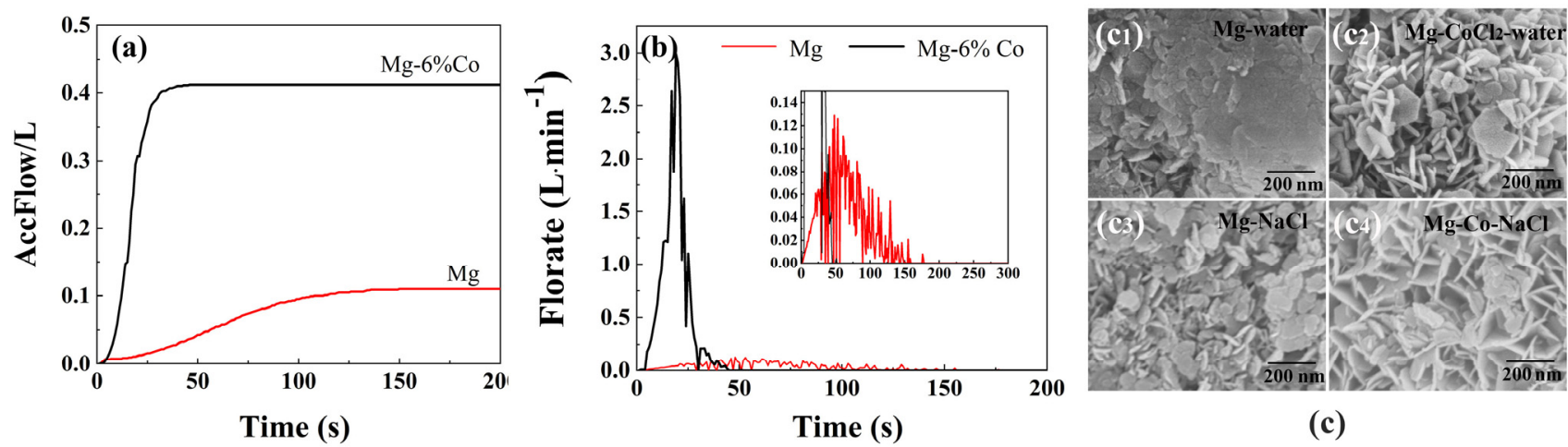

(c)

Figure 9. (a) Hydrogen generation curves of the $\mathrm{Mg}-6 \% \mathrm{Co}$ with $\mathrm{NaCl}$ solute, (b) the hydrogen generation rate and (c) SEM images of reaction productions. 
Table 3. Hydrogen generation properties of ball-milled $\mathrm{Mg}-6 \% \mathrm{Co}$ with water and $\mathrm{NaCl}$ solute.

\begin{tabular}{ccccccc}
\hline \multirow{0}{*}{$\mathbf{0 . 5} \mathbf{g}$} & HGR & Tap Water & \multicolumn{3}{c}{ NaCl Solute } \\
\cline { 2 - 7 } & $\mathbf{( L )}$ & $\begin{array}{c}\text { Conversion Yield } \\
\mathbf{( \% )}\end{array}$ & $\begin{array}{c}\text { MHGR } \\
\left(\mathbf{L} \cdot \mathbf{m i n}^{-\mathbf{1}}\right)\end{array}$ & $\begin{array}{c}\text { HGR } \\
(\mathbf{L})\end{array}$ & $\begin{array}{c}\text { Conversion Yield } \\
(\mathbf{\%})\end{array}$ & $\begin{array}{c}\text { MHGR } \\
\left(\mathbf{L} \cdot \mathbf{m i n}^{-\mathbf{1}}\right)\end{array}$ \\
\hline $\mathrm{Mg}$ & 0.000 & 0.0 & 0.000 & 0.108 & 23.1 & 0.132 \\
\hline $\mathrm{Mg}-6 \% \mathrm{Co}$ & 0.000 & 0.0 & 0.000 & 0.421 & 90.1 & 3.001 \\
\hline
\end{tabular}

Figure 9c shows the SEM images of the hydrolysis reaction productions for different reaction systems. The morphology of $\mathrm{Mg}(\mathrm{OH})_{2}$ changes from large flakes into independent self-assembled ones with the participation of $\mathrm{NaCl}$ for the reaction ball milling $\mathrm{Mg}$ with water (see Figure 9(c1,c3)). The addition of $\mathrm{NaCl}$ to the solute improves the crystallization behavior during the formation of $\mathrm{Mg}(\mathrm{OH})_{2}$ [29] and self-assembled $\mathrm{Mg}(\mathrm{OH})_{2}$ flakes fall much easier off from the $\mathrm{Mg}$ powder surface. In this way, more unreacted fresh $\mathrm{Mg}$ tends to be exposed and the hydrolysis reaction is promoted. The productions of $\mathrm{Mg}-\mathrm{CoCl}_{2}-\mathrm{H}_{2} \mathrm{O}$ and $\mathrm{Mg}-\mathrm{Co}-\mathrm{NaCl}-\mathrm{H}_{2} \mathrm{O}$ reaction systems show similar self-assembled morphologies as seen in Figure 9(c2,c4), which means that the $\mathrm{Co}_{0}$ and $\mathrm{Cl}^{-}$are both essential in promoting the hydrolysis reaction of $\mathrm{Mg}$.

\subsection{The Evolutions during Ball Milling $\mathrm{Mg}$ with $\mathrm{CoCl}_{2}$}

\subsubsection{The Morphology Change of Mg Powder after Ball Milling with $\mathrm{CoCl}_{2}$}

Nano CT was adopted to characterize the inner microstructure of ball milling $\mathrm{Mg}$ and $\mathrm{Mg}-\mathrm{CoCl}_{2}$ powders, and Figure 10 gives the typical corresponding slice of ball milling powders (powder size $<60 \mu \mathrm{m}$ ). Spherical $\mathrm{Mg}$ powder changed into flakes with the thickness of 10-20 $\mu \mathrm{m}$ after ball milling for $3 \mathrm{~h}$ as seen in Figure 10a. No cracks exist both on the powder's surface and interior for ball milling pure Mg powder. However, numerous cracks are generated with varying sizes both on the surface and interior after ball milling with $\mathrm{CoCl}_{2}$ for $3 \mathrm{~h}$ as shown in Figure 10b. These cracks are effective in exposing the fresh $\mathrm{Mg}$ and thus activate the hydrolysis reaction of $\mathrm{Mg}$. It is interesting to see that some white particles are embedded inside the $\mathrm{Mg}$ flake as marked in Figure 10b. The white particles have higher density according to the phase contrast and are assumed to be Co particles in this system.
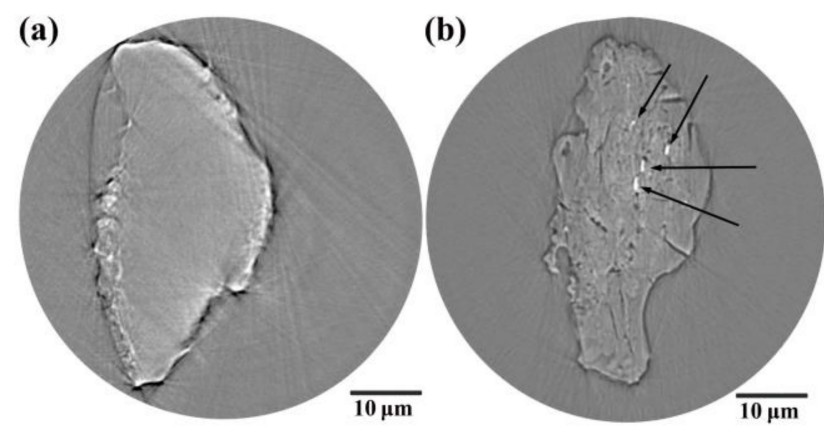

Figure 10. The typical slice of $3 \mathrm{~h}$ ball milling powders (a) $\mathrm{Mg}$, (b) $\mathrm{Mg}-6 \% \mathrm{CoCl}_{2}$.

\subsubsection{The Evolution of $\mathrm{Co}^{2+}$ during Ball Milling $\mathrm{Mg}$ with $\mathrm{CoCl}_{2}$}

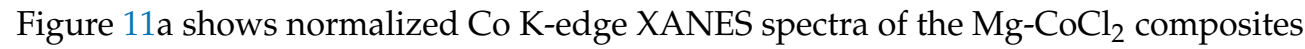
as well as the reference samples of $\mathrm{Co}$ foil and $\mathrm{CoCl}_{2}$. A higher valence of $\mathrm{Co}$ usually has an absorption edge shifting toward higher energy. Pure $\mathrm{CoCl}_{2}$ features two peaks (A and B) of higher intensity and higher absorption edge. The XANES curves for $3 \mathrm{~h}$ ball-milled $\mathrm{Mg}-\mathrm{CoCl}_{2}$ composites powder change a lot, both in intensity and absorption edge. The absorption edge shifts toward lower photon energy, the first peak $\mathrm{A}$ is lower and peak B disappeared relative to the $\mathrm{CoCl}_{2}$, as shown in Figure 10a. These changes reveal the 
negative charge in comparison with the $\mathrm{CoCl}_{2}$, likely because $\mathrm{Mg}$ is an electron-donor. The obvious energy shift indicates the further electron transfer from the $\mathrm{Mg}$ atom to the $\mathrm{Co}^{2+}$ after ball milling for $3 \mathrm{~h}$. The curve of $\mathrm{Mg}_{-} \mathrm{CoCl}_{2}$ is more akin to Co foil, showing an intermediate state between metallic $\mathrm{Co}$ and $\mathrm{CoCl}_{2}$. Figure $11 \mathrm{~b}$ shows the Fourier transform of the Co K-edge EXAFS oscillations in R space (phase-shift correction was not performed). The first nearest-neighbor distance for $\mathrm{Co}$ in $\mathrm{Mg}-\mathrm{CoCl}_{2}$ composite changed a lot compared with $\mathrm{CoCl}_{2}$, with only one single peak at the first nearest-neighbor distance being observed. This peak indicates the generation of metallic $\mathrm{Co}$, which further confirms the assumption in the CT slice data (Figure 10b).
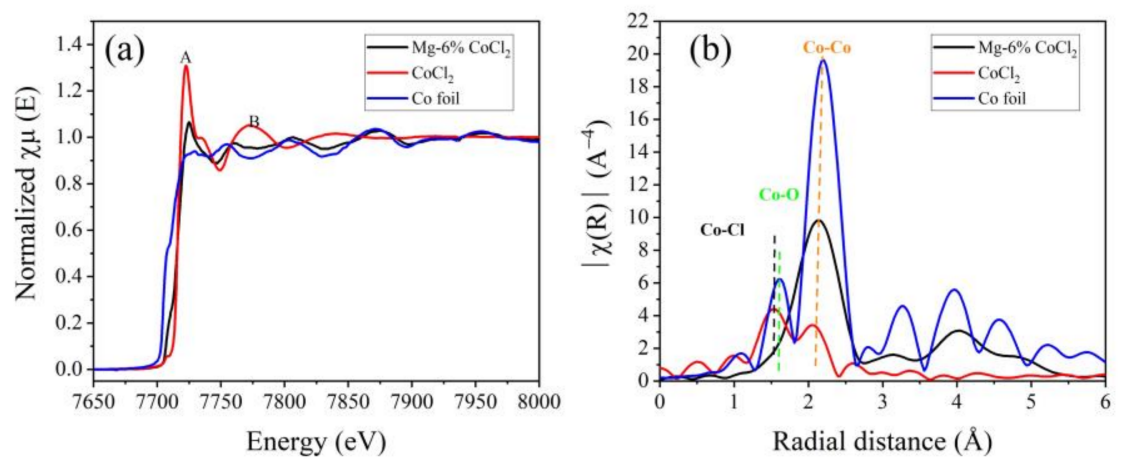

Figure 11. (a) Normalized XANES spectra at the Co K-edge, (b) Fourier-transformed extended X-ray absorption fine structure (EXAFS) of the $\mathrm{Mg}-\mathrm{CoCl}_{2}$ samples together with $\mathrm{CoCl}_{2}$ and $\mathrm{Co}$ foil.

\subsection{The Activation Mechanism}

Figure 12 shows The activation mechanism. The dual existing of $\mathrm{Co}$ and $\mathrm{Cl}^{-}$are essential in the activation of ball milling $\mathrm{Mg}$ powder as discussed in Section 4.2. For the ball milling $\mathrm{Mg}-\mathrm{CoCl}_{2}$ composite, the reduction reaction of cobalt ions occurs during ball milling and metallic Co generated $\left(\mathrm{Co}^{2+}+\mathrm{Mg} \rightarrow \mathrm{Co}+\mathrm{Mg}^{2+}\right)$ according to the results in Sections 4.2 and 4.3. The mechanism for the activation of $\mathrm{Mg}$ powder promoted by chloride during ball milling can be concluded as follows:

1. Ball milling effect-The large number of cracks generated as the Mg powder with chloride is squashed and overlapped during ball milling. This leads to the exposure of fresh $\mathrm{Mg}$ and gives more active positions for $\mathrm{Mg}$-water reaction. In addition, high potential metallics were generated as the reduction reaction occurred during ball milling promotes the corrosion of $\mathrm{Mg}$.

2. The dual promoting effect of $\mathrm{Cl}^{-}-$The existence of $\mathrm{Cl}^{-}$in the system has two functions: one is acting as electrolyte for the $\mathrm{Mg}-\mathrm{M}$ galvanic cell which accelerates the corrosion of $\mathrm{Mg}$; the other is as the crystallization promoter, which modified the $\mathrm{Mg}(\mathrm{OH})_{2}$ into self-assembled morphology that easily falls off from the surface of the Mg.

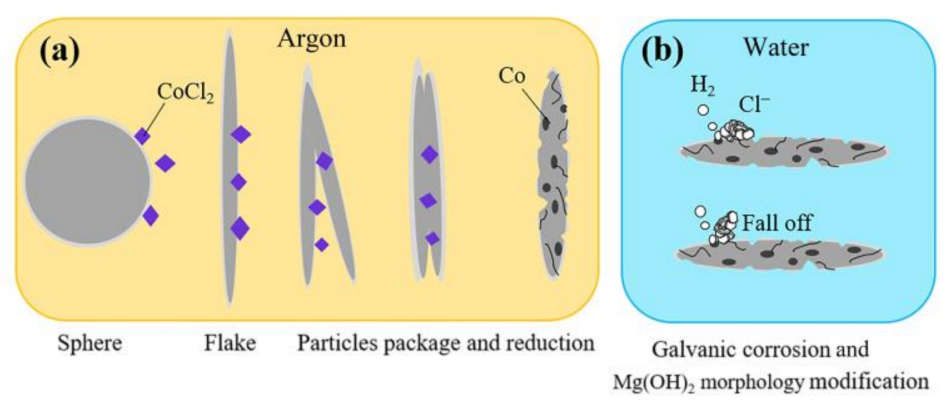

Figure 12. The activation mechanism, (a) ball milling process, (b) hydrolysis process. 


\section{Conclusions}

In this paper, active Mg powder was prepared by ball milling with different chlorides. A much more intense and faster water reaction rate was observed after ball-milling with $\mathrm{Mg}$ powder and chloride compared to pure $\mathrm{Mg}$. The best hydrogen performance is obtained in the $\mathrm{Mg}-6 \% \mathrm{CoCl}_{2}$ composite, which presents a high hydrolysis conversion rate of up to $96.6 \%$, as well as a hydrogen production of $423 \mathrm{~mL} /(0.5 \mathrm{~g})$. Ball milling $\mathrm{Mg}$ and chlorides can produce surface defects, the reduction of new high potential metallic atoms. The defects generated lead to the exposure of fresh surfaces and result in a lower binding and corrosion potential compared with pure $\mathrm{Mg}$. The high potential metallic atom generated promotes the corrosion of $\mathrm{Mg}$ under the existence of $\mathrm{Cl}^{-}$. In addition, the $\mathrm{Cl}^{-}$acts as the crystallization promoter, which modified the $\mathrm{Mg}(\mathrm{OH})_{2}$ into a self-assembled morphology that easily falls from the surface of the $\mathrm{Mg}$.

Author Contributions: Conceptualization, M.Z. and S.W.; experiments, X.W., L.Z. and X.Z.; formal analysis, S.W. and T.S.; funding acquisition, S.W.; project administration, M.Z. and S.W.; writing original draft, S.W., X.W. and X.G.; writing review and editing, S.W., X.W., M.Z. and X.L. All authors have read and agreed to the published version of the manuscript.

Funding: Postdoctoral Research Foundation of China, grant number 2019M660483.

Institutional Review Board Statement: Not applicable.

Informed Consent Statement: Not applicable.

Data Availability Statement: Data sharing not applicable.

Acknowledgments: The authors would like to thank the Postdoctoral Research Foundation of China (No. 2019M660483) for financial support; The authors also would like to thank the support given by the beamline scientist, Chunxia Yao at beamline $4 \mathrm{~W} 1 \mathrm{~A}-\mathrm{X}$ and Zhongjun Zheng at beamline $4 \mathrm{~B} 9 \mathrm{~A}$ of the Beijing Synchrotron Radiation Facility (BSRF).

Conflicts of Interest: The authors declare no conflict of interest.

\section{References}

1. Bauen, A. Future energy sources and systems-Acting on climate change and energy security. J. Power Sources 2006, 157, 893-901. [CrossRef]

2. Broom, D.P.; Webb, C.J.; Hurst, K.E.; Parilla, P.A.; Gennett, T.; Brown, C.M.; Zacharia, R.; Tylianakis, E.; Klontzas, E.; Froudakis, G.E.; et al. Outlook and challenges for hydrogen storage in nanoporous materials. Appl. Phys. A 2016, 122, 151. [CrossRef]

3. Guillen, C.; Herrero, J. TCO/metal/TCO structures for energy and flexible electronics. Thin Solid Films 2011, 520, 1-17. [CrossRef]

4. Schapbach, L.; Zuttel, A. Hydrogen-storage materials for mobile applications. Nature 2001, 414, 353-358. [CrossRef] [PubMed]

5. Fan, M.Q.; Liu, S.S.; Zhang, Y.; Zhang, J.; Sun, L.-X.; Xu, F. Superior hydrogen storage properties of MgH2-10 wt.\% TiC composite. Energy 2010, 35, 3417-3421. [CrossRef]

6. Fan, M.Q.; Sun, L.-X.; Xu, F. Experiment assessment of hydrogen production from activated aluminum alloys in portable generator for fuel cell applications. Energy 2010, 35, 2922-2926. [CrossRef]

7. Kaur, M.; Pal, K. Review on hydrogen storage materials and methods from an electrochemical viewpoint. J. Energy Storage 2019, 23, 234-249. [CrossRef]

8. Fukuchi, A.; Kawashima, M.; Yuasa, S. Combustion characteristics of $\mathrm{Mg}-\mathrm{CO}_{2}$ counterflow diffusion flames. Symp. Combust. 1996, 26, 1945-1951. [CrossRef]

9. Shafirovich, E.Y.; Goldshleger, U.I. Combustion of magnesium particles in $\mathrm{CO}_{2} / \mathrm{CO}$ mixtures. Combust. Sci. Technol. 1992, 84, 33-43. [CrossRef]

10. Foote, J.; Litchford, R. Powdered magnesium-carbon dioxide combustion for mars propulsion. In Proceedings of the 41st AIAA/ASME/SAE/ASEE Joint Propulsion Conference and Exhibit, Tucson, Arizona, 10-13 July 2005; p. 4469.

11. Shevtsov, V.I.; Fursov, V.P.; Stesik, L.N. Mechanism for combustion of isolated magnesium particles. Combust. Explos. Shock. Waves 1976, 12, 758-763. [CrossRef]

12. Mason, J.E. World energy analysis: $\mathrm{H} 2$ now or later? Energy Policy 2007, 35, 1315-1329. [CrossRef]

13. Hou, X.; Wang, Y.; Yang, Y.; Hu, R.; Yang, G.; Feng, L.; Suo, G. Microstructure evolution and controlled hydrolytic hydrogen generation strategy of Mg-rich Mg-Ni-La ternary alloys. Energy 2019, 188, 116081. [CrossRef]

14. Xiao, F.; Guo, Y.; Yang, R.; Li, J. Hydrogen generation from hydrolysis of activated magnesium/low-melting-point metals alloys. Int. J. Hydrog. Energy 2019, 44, 1366-1373. [CrossRef]

15. Gupta, R.B. Hydrogen Fuel: Production, Transport, and Storage, 1st ed.; CRC Press: Boca Raton, FL, USA, 2009. 
16. Macanás, J.; Soler, L.; Candela, A.M.; Muñoz, M.; Casado, J. Hydrogen generation by aluminum corrosion in aqueous alkaline solutions of inorganic promoters: The AlHidrox process. Energy 2011, 36, 2493-2501. [CrossRef]

17. Parmuzina, A.V.; Kravchenko, O.V. Activation of aluminium metal to evolve hydrogen from water. Int. J. Hydrog. Energy 2008, 33, 3073-3076. [CrossRef]

18. Kushch, S.D.; Kuyunko, N.S.; Nazarov, R.S.; Tarasov, B.P. Hydrogen-generating compositions based on magnesium. Int. J. Hydrog. Energy 2011, 36, 1321-1325. [CrossRef]

19. Grosjean, M.H.; Zidoune, M.; Roué, L. Hydrogen production from highly corroding Mg-based materials elaborated by ball milling. J. Alloy. Compd. 2005, 404-406, 712-715. [CrossRef]

20. Grosjean, M.H.; Zidoune, M.; Roué, L.; Huot, J.Y. Hydrogen production via hydrolysis reaction from ball-milled Mg-based materials. Int. J. Hydrog. Energy 2006, 31, 109-119. [CrossRef]

21. Huang, M.; Ouyang, L.; Ye, J.; Liu, J.; Yao, X.; Wang, H.; Shao, H.; Zhu, M. Hydrogen generation via hydrolysis of magnesium with seawater using $\mathrm{Mo}, \mathrm{MoO}_{2}, \mathrm{MoO}_{3}$ and $\mathrm{MoS}_{2}$ as catalysts. J. Mater. Chem. A 2017, 5, 8566-8575. [CrossRef]

22. Huang, H.T.; Zou, M.S.; Guo, X.Y.; Yang, R.J.; Li, Y.K. Study of reactions of activated Mg-based powders in heated steam. J. Power Sources 2014, 246, 960-964. [CrossRef]

23. Zou, M.; Guo, X.; Huang, H. Preparation and characterization of hydro-reactive Mg-Al mechanical alloy materials for hydrogen production in seawater. J. Power Sources 2012, 219, 60-64. [CrossRef]

24. Matsuzaki, K.; Murakami, T. Formation of Hydrogen by Ball Milling of Mg and Mg Alloy in Seawater. Mater. Sci. Forum 2017, 879, 1265-1269. [CrossRef]

25. Kravchenko, O.V.; Sevastyanova, L.G.; Urvanov, S.A.; Bulychev, B.M. Formation of hydrogen from oxidation of Mg, Mg alloys and mixture with $\mathrm{Ni}, \mathrm{Co}, \mathrm{Cu}$ and $\mathrm{Fe}$ in aqueous salt solutions. Int. J. Hydrog. Energy 2014, 39, 5522-5527. [CrossRef]

26. Liu, Y.; Wang, X.; Dong, Z.; Liu, H.; Li, S.; Ge, H.; Yan, M. Hydrogen generation from the hydrolysis of Mg powder ball-milled with $\mathrm{AlCl}_{3}$. Energy 2013, 53, 147-152. [CrossRef]

27. Wang, X.; Zhang, Q.; Shi, X.; Wang, N.; Chai, Y. Synergistic effect of the fresh Co, Ni, and anion ions on aluminum or magnesium with water reactions. Int. J. Energy Res. 2019, 43, 430-438. [CrossRef]

28. Sun, Q.; Zou, M.; Guo, X.; Yang, R.; Huang, H.; Huang, P.; He, X. A study of hydrogen generation by reaction of an activated $\mathrm{Mg}-\mathrm{CoCl}_{2}$ (magnesium-cobalt chloride) composite with pure water for portable applications. Energy 2015, 79, 310-314. [CrossRef]

29. Song, X.; Sun, S.; Zhang, D.; Wang, J.; Yu, J. Synthesis and characterization of magnesium hydroxide by batch reaction crystallization. Front. Chem. Sci. Eng. 2011, 5, 416-421. [CrossRef] 